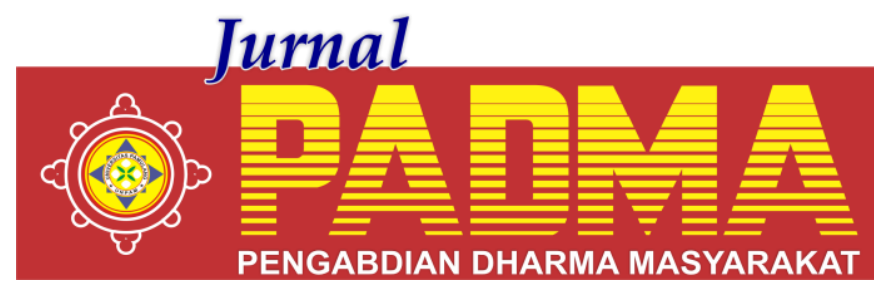

VOLUME 1, NOMOR 4, OKTOBER 2021

\title{
MENJAGA KEBERSIHAN UNTUK BUMI KITA TERCINTA DI PONDOK PESANTREN DARUL FURQON RAMADHAN GUNUNG SINDUR, KABUPATEN BOGOR JAWA BARAT
}

\author{
1Indra Saputra, ${ }^{2}$ Haetami, ${ }^{3}$ Jaenudin, 4 Mak'ruf, 5*Nanang \\ Universitas Pamulang, Tangerang Selatan, Banten, Indonesia \\ *nnanang.155@gmail.com
}

\begin{abstract}
Abstrak
Sampah telah menjadi masalah klasik di Indonesia termasuk salah satunya di Bogor. Sampah dengan segenap permasalahan yang dihadapi kota bogor tidak hanya mempengaruhi estetika, kebersihan, dan kenyamanan kota, juga berpengaruh terhadap kesehatan penduduk dan lingkungan kota sebagai akibat dari produksi dan polusi sampah. Untuk mewujudkan lingkungan kabupaten bogor yang sehat dan bersih dari sampah sehingga penduduknya merasa nyaman dan bebas dari polusi sampah, diperlukan pengelolaan sampah secara terpadu oleh semua pihak.
\end{abstract}

Kata Kunci: Sampah, Kebersihan

\section{Abstract}

Garbage has become a classic problem in Indonesia including one in Bogor. Waste with all the problems faced by the city of Bogor not only affects the aesthetics, cleanliness, and comfort of the city, it also affects the health of the population and the environment of the city as a result of waste production and pollution. To realize a healthy and clean bogor regency environment from waste so that its residents feel comfortable and free from waste pollution, integrated waste management is needed by all parties. Keywords: Garbage, Cleanliness

\section{PENDAHULUAN}

Kebersihan merupakan satu hal yang paling penting dan harus selalu dijaga agar lingkungan menjadi bersih, nyaman dan terbebas dari berbagai macam penyakit. Kebersihan tidak hanya dilakukan dirumah saja melainkan disemua tempat yang kita tinggali seperti sekolah, kantor dan tempat ibadah. Apabila kebersihan tidak dijaga maka bisa menimbulkan berbagai penyakit. Pada era modern ini masyarakat mulai banyak yang tidak peduli dengan kebersihan lingkungan, kebanyakan dari mereka bersikap anti sosial sehingga budaya gotong royong untuk membersihkan lingkungan sudah berkurang. Hal ini tentunya akan membuat lingkungan menjadi kotor. Oleh karena itu diperlukan menyadari masyarakat akan pentingnya gotong royong membersihkan lingkungan.

Lingkungan merupakan tempat dimana manusia hidup yang mana merupakan salah satu elemen kehidupan. Lingkungan merupakan salah satu faktor yang dapat mempengaruhi kehidupan manusia. Lingkungan dapat mewarnai segala aktifitas kehidupan manusia, mulai dari gaya hidup cara berprilaku, pola pikir, bahkan kepribadian. Didalam lingkungan dimana manusia hidup terdiri dari berbagai elemen yang merupakan faktor pembentuk lingkungan. diantaranya yaitu masyarakat. Masyarakat merupakan kumpulan dari berbagai individu manusia yang saling berinteraksi dan mempunyai suatu tujuan tertentu. Interaksi antar individu tersebut mengakibatkan suatu hubungan kekerabatan yang dapat dijadikan suatu sarana komunikasi dalam rangka membentuk suatu himpunan kemasyarakatan. Lingkungan merupakan tempat hidup manusia. Oleh karena itu sudah sepatutnya jika menjadikan lingkungan tempat tinggal menjadi senyaman mungkin. Sehingga dapat menimbulkan suatu keselarasan bagi individu yang mendiaminya. Salah satu cara untuk menjaga kenyamanan lingkungan yaitu dengan cara mencanangkan dan memprioritaskan kebersihan baik itu kebersihan individu maupun kebersihan lingkungan tempat tinggi. 
Berdasarkan latar belakang tersebut, kami tim program pengabdian masyarakat (PKM) Universitas Pamulang (UNPAM) yang berjumlah 5 orang mahasiswa terpanggil untuk ikut serta membantu memecahkan persoalan yang dihadapi oleh organisasi masyarakat tersebut dengan judul PKM : "Menjaga Kebersihan Untuk Bumi kita Tercinta" Di Pondok Pesantren Darul Furqon Ramadhan Gunung Sindur ,Kabupaten Bogor, Jawa Barat."

Ketercapaian target luaran dari kegiatan pengabdian masyarakat dengan kelompok sasaran kepada anak-anak pesantren di Pondok Pesantren Darul Furqon Ramadhan Gunung Sindur ,Kabupaten Bogor, Jawa Barat yang kami lakukan dapat dilihat dari tiga hal. Pertama, ketercapaian tujuan kegiatan sesuai dengan tujuan yang ada pada rencana yang telah disusun di dalam proposal. Kedua, terpublikasikanya aktifitas kegiatan pengabdian kepada masyarakat yang dilakukan oleh tim pengabdi anak-anak pesantren di Pondok Pesantren Darul Furqon Ramadhan Gunung Sindur ,Kabupaten Bogor, Jawa Barat.

Kebersihan lingkungan merupakan keadaan bebas dari kotoran, termasuk di dalamnya, debu, sampah, dan bau. Di Indonesia, masalah kebersihan lingkungan selalu menjadi perdebatan dan masalah yang berkembang. Kasus-kasus yang menyangkut masalah kebersihan lingkungan setiap tahunnya terus meningkat.

Problem tentang kebersihan lingkungan yang tidak kondusif dikarenakan masyarakat selalu tidak sadar akah hal kebersihan lingkungan. Tempat pembuangan kotoran tidak dipergunakan dan dirawat dengan baik. Akibatnya masalah diare, penyakit kulit, penyakit usus, penyakit pernafasan dan penyakit lain yang disebabkan air dan udara sering menyerang golongan keluarga ekonomi lemah. Berbagai upaya pengembangan kesehatan anak secara umum pun menjadi terhambat.

Manfaat Menjaga Kebersihan Lingkungan Sekitar

1. Lingkungan Jadi Lebih Sehat

Kebersihan selalu identik dengan kesehatan.Artinya, menjaga lingkungan sama dengan menjaga kesehatanmu
juga.Lingkungan yang bersih dan terjaga dapat membuat kamu terhindar dari berbagai macam penyakit.Hal tersebut karena, lingkungan kotor adalah tempat yang sering dijadikan sarang oleh nyamuk, tikus, kecoa, dan bakteri.Binatang tersebut merupakan sumber dari berbagai penyakit mematikan yang bisa kena ke manusia.Menjaga kebersihan lingkungan di tempat tinggal, sekolah, dan rumah ibadah dapat membuat masyarakat terhindar dari berbagai penyakit

2. Linkungan Sehat Berkaitan dengan Kesehatan Mental

Tidak hanya kesehatan fisik saja, tapi lingkungan yang sehat juga dapat membuat kesehatan mental terjaga.Dilansir dari The United Nations Environment Programme, lingkungan yang sehat memiliki manfaat yang besar bagi kesehatan mental seseorang.Udara yang bersih, banyaknya ruang hijau, dan sanitasi dapat meningkatkan kualitas hidup seseorang.Meningkatkan kualitas hidup tentu akan membuat seseorang terhindar dari gangguan mental.Menghabiskan waktu pada lingkungan yang memiliki banyak ruang terbuka hijau dapat menurunkan tingkat kecemasan dan juga depresi.

3. Lingkungan Sehat Lebih Nyaman untuk Ditinggali

Tentunya lingkungan yang kotor dan kumuh membuat kamu merasa tidak nyaman lama-lama berada di tempat tersebut.Bahkan sering kali kita malas untuk mendekati atau mengunjungi lingkungan yang kotor.Lingkungan yang bersih membuat kamu lebih nyaman untuk tinggal dan menetap dalam waktu lama.Selain itu, orang-orang juga akan merasa senang untuk berkunjung ke rumah dengan lingkungan bersih.

4. Terhindar dari Ancaman Banjir

Banjir adalah salah satu dampak buruk dari lingkungan yang tidak bersih. Penyebab banjir yaitu kaena membuang sampah tidak pada tempatnya, yang mengakibatkan banyaknya sampah yang berserakan dimana-mana. Sehingga ketika terjadi hujan, sampah tersebut akan diseret oleh air dan menutupi lubang selokan, yang mengakibatkan air 
tidak dapat mengalir dengan sempurna. Dengan begitu air akan menggenangi duatu jalan bahkan perumahan. Air akan surut beberapa waktu kemudian, ada yang hitungan jam bahkan ada yang hitungan hari.Sangat seram bukan, jika tinggal di daerah rawan banjir. Kita akan kesulitan untuk melakukan aktivitas kita.Sebaliknya, dengan kebersihan kita mampu menghindari banjir tersebut.

5. Terhindar dari Penyakit Menular Penyakit menular dampak lingkungan kotor adalah DBD, diare, dan tipes. Penyakit tersebut jika tidak diobati dengan benar akan berujung pada kematian. Banyak masyarakat yang takut terhadap ancaman, namun masih sedikit yang melakukan pencegahan terhadap faktor risiko penyakit tersebut. Hal ini yang mengakibatkan, masih banyaknya penyakit yang disebabkan karena lingkungan yang tidak bersih. Hanya kerugian yang kita dapatkan jika tidak menghindari penyakit tersebut.Dengan melakukan pencegahan-pencegahan seperti memelihara kebersihan lingkungan sekitar dengan tidak membuang sampah sembarangan, $\mathrm{BAB}$ sembarangan, dan lain sebagianya, kita mampu untuk menghindari penyakitpenyakit tersebut. Lingkungan yang bersih akan membuat kita hidup aman, nyaman, dan tetram.

6. Meningkatkan Kesehatan Jasmani dan Rohani

Kebersihan adalah modal utama kesehatan jasmani dan rohani. Terdapat kutipan dari puisi Satire yang ditulis indah oleh Decimus Iunius Iuvenalis, seorang penyair dan filosofi Romawi yang berbunyi "Mens Sana In Corpore Sano" atau yang berarti, didalam tubuh yang sehat terdapat jiwa yang kuat. Ia menegaskan bahwa manfaat budaya bersih sebuah bangsa mencerminkan kemajuan berpikir bangsa tersebut.Sudut pandang bersih yang sederhana berasal dari rumah kita sendiri. Rumah yang bersih akan mendatangkan energi ketenangan dan kekuatan serta kesehatan, baik itu sehat jasmani maupun rohani

\section{METODE}

Metode kegiatan yang dilakukan dalam rangka menyukseskan kegiatan pengabdian ini, yaitu:

1. Peralatan yang dibutuhkan untuk melaksanan kegiatan ini

Pada tahapan ini pelaksana memulai dengan melakukan koordinasi dengan instansi terkait.

2. Penentuan Lokasi

Pada tahap ini dilakukan kunjungan ke lokasi untuk menentukan tempat (lokasi). Dalam memilih lokasi, kami mempertimbangkan dengan jarak yang kami tempuh dari Universitas ke lokasi pengabdian.

3. Perancangan kebutuhan

Adapun tahapan yang dilakukan dalam perancangan kebutuhan secara berurutan adalah sebagai berikut:

a) Perancangan materi tentang pentingnya menjaga lingkugan untuk bumi kita tercinta sejak dini

b) Perancangan materi tentang manfaat dan dampak menjaga lingkugan

c) Perancangan alat yang dibutuhkan sebagai berikut:

- Menyiapkan proyektor.

d) Metode pendekatan yang digunakan dalam kegiatan ini adalah :

- Persentasi

- Tanya Jawab

- Diskusi / sharing

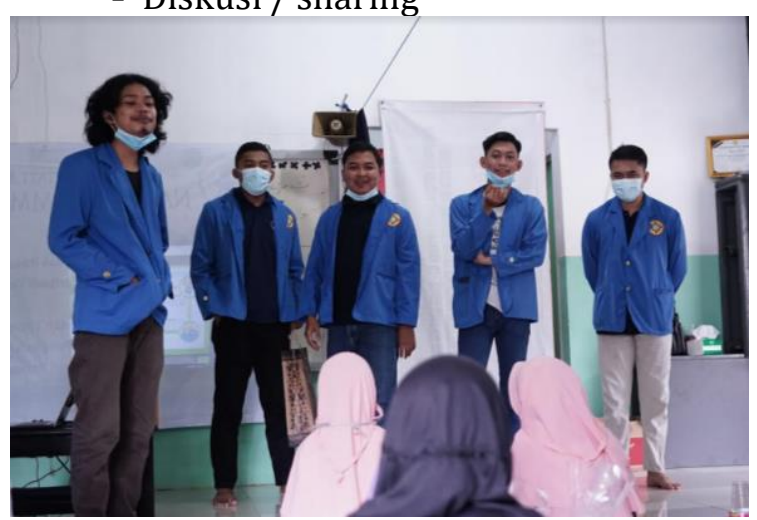

Gambar 1. Para Narasumber

Dalam upaya mencari solusi atas permasalahan yang dihadapi oleh peserta maka kami menawarkan target solusi dalam penyelesaian sesuai dengan target yang sudah kami siapkan dan kami sepakati dengan pihak mitra. Adapun solusi tersebut akan kami laporkan dalam bentuk luaran 
kegiatan PKM yang terdiri dari beberapa tahapan.

\section{HASIL DAN PEMBAHASAN}

Kebersihan lingkungan merupakan hal yang tak terpisahkan dari kehidupan manusia dan merupakan unsur yang fundamental dalam ilmu kesehatan dan pencegahan.Pentingnya menjaga lingkungan wajib harus kita tanamkan sejak dini. Penebangan hutan secara liar/pembalakan hutan, polusi air dari limbah industri dan pertambangan, polusi udara di daerah perkotaan, dan masalah mengenai rusaknya lingkungan kita khususnya di Indonesia bukan merupakan masalah yang baru lagi, yang seharusnya dibenahi sesegera mungkin. Bagaimana tidak, masalah ini tidak luput dari peran pemerintah dan masyarakat yang harus berdampingan menjaga lingkungan kita ini.

Kegiatan edukasi tentang pentingnya menjaga lingkugan untuk bumi kita tercinta sejak dini di pondok pesantren Darul Furqon Ramadhan Gunung Sindur ,Kabupaten Bogor, Jawa Barat ini ini dapat disimpulkan berhasil sampai dengan tahap diskusi serta tanya jawab tentang betapa pentingnya kita menjaga lingkungan. Keberhasilan ini ditunjukkan antara lain oleh:

1. Adanya kesesuain materi dengan keadaan lingkungan pondok pesantren Darul Furqon Ramadhan Gunung Sindur ,Kabupaten Bogor, Jawa Barat

2. Adanya respon positif dari pengurus serta anak-anak di pondok pesantren Darul Furqon Ramadhan Gunung Sindur ,Kabupaten Bogor, Jawa Barat yang ditunjukkan dengan berbagai pertanyaan yang mereka sampaikan.

3. Pengurus serta anak-anak di pondok pesantren Darul Furqon Ramadhan telah memahami bagaimana pentingnya menjaga lingkugan untuk bumi kita tercinta sejak dini

\section{PENUTUP}

Saran yang diberikan dari kegiatan pengabdian kepada masyarakat yang dilakukan oleh tim pengabdian masyarakat mahasiswa manajemen, Fakultas Ekonomi, Universitas Pamulang kepada lingkungan di pondok pesantren Darul Furqon Ramadhan
Gunung Sindur ,Kabupaten Bogor, Jawa Barat adalah sebagai berikut;

a. Bagi pengurus pondok pesantren Darul Furqon Ramadhan, Jawa Barat agar selalu menanamkan sejak dini untuk selalu memberikan edukasi betapa pentingnya menjaga lingkungan pesantren untuk kesehatan serta keindaan semua.

b. Pelatihan serupa dapat dilaksanakan kembali dengan peserta (audience) yang lebih banyak/luas, dan dengan topik lainnya yang lebih menarik serta membangun.

\section{DAFTAR PUSTAKA}

Ajimat, A., et al. (2020). Berwirausaha Memanfaatkan Media Sosial Pada Daerah Sepatan. ADI Pengabdian Kepada Masyarakat, 1(1), 69-76.

Kembara, M. D., et al (2020). Scientific Literacy Profile Of Student Teachers On Science For All Context. Solid State Technology, 63(6), 5844-5856.

Khoiri, A., et al. (2021, February). 4Cs Analysis of 21st Century Skills-Based School Areas. In Journal of Physics: Conference Series (Vol. 1764, No. 1, p. 012142). IOP Publishing.

Paeno, P., et al. (2020). Pemanfaatan Sampah Plastik Untuk Kerajinan Rumah Tangga Taman Belajar Kreatif Mekar Sari. BAKTIMAS: Jurnal Pengabdian pada Masyarakat, 2(1), 57-61.

Rozi, A., et al. (2021, February). The fullness of Higher Order Thinking Skills (HOTs) in Applied Science Textbooks of Vocational Schools. In Journal of Physics: Conference Series (Vol. 1764, No. 1, p. 012143). IOP Publishing.

Sampurnaningsih, S. R., et al. (2020). The Analysis of Entrepreneurship Character and Entrepreneurship Intention among Students. PalArch's Journal of Archaeology of Egypt/Egyptology, 17(6), 8290-8303.

Yuangga, K. D., et al. (2020). Pengembangan media dan strategi pembelajaran untuk mengatasi permasalahan pembelajaran jarak jauh di pandemi covid-19. JGK (Jurnal Guru Kita), 4(3), 51-58. 